\title{
Effect of Soil Amplification on the Response of Base-Isolated Buildings under Near-Fault Earthquakes
}

\author{
Sinan Sargın, Hatice Gazi, Cenk Alhan, Sadik Oztoprak \\ Department of Civil Engineering, İstanbul University \\ Avc1lar Campus, İstanbul, Turkey \\ ssargin@istanbul.edu.tr; hgazi@istanbul.edu.tr; cenkalhan@ istanbul.edu.tr; oztoprak@istanbul.edu.tr
}

\begin{abstract}
Near-fault earthquakes (i.e. strong ground motion records obtained in near-fault zones) are known to challenge baseisolated buildings with their capacity to create large isolation system displacements. Such earthquake records typically contain velocity pulses with long periods and thus threaten base-isolated buildings which also have long fundamental periods that may coincide with the pulse periods of the near-fault earthquakes. In case base-isolated buildings are located in near-fault regions where soil amplification may be observed, it may worsen the situation further. In order to investigate the effect of soil amplification on the response of baseisolated buildings which are located in near-fault zones, a synthetic pulse representing near-fault earthquake records is created and a soil amplification analysis is conducted on this record for a representative benchmark soft soil. A benchmark base-isolated building is then subjected to the original and the amplified record. Finally, the peak values of the seismic response parameters such as the isolation system displacement, floor accelerations, and story shears are compared.
\end{abstract}

Keywords: Soil amplification, Near-fault earthquake, Seismic base-isolation, Earthquake engineering, Geotechnical earthquake engineering.

\section{Introduction}

In order to estimate the dynamic behavior of the structures and facilities under earthquake loadings accurately, a good estimation of the ground amplification level during the expected earthquake is required. The local soil conditions of specific sites have significant influences on the vulnerability of engineering structures. Depending on the subsurface characteristics, seismic waves might undergo amplification and create more severe strong motions at the surface. Many earthquake prone cities are settled over very susceptible areas with young deposits such as Mexico City [1] and Loma Prieta [2]. Borcherdt et al. [3] conducted a series of seismological studies on the aftershocks following the earthquakes of December 7, 1988 near Spitak, Armenia. The measurements of relative ground response indicated that ground motions in the period band 0.5 to 2.5 seconds were amplified significantly by the local geological conditions. Moreover, damage statistics were in good agreement with these observations.

One-dimensional numerical approaches for conducting ground response analysis require input parameters such as local soil profile that includes strength and index parameters of soils, bedrock level, and acceleration records of design earthquake. The level of shaking is usually described in terms of peak ground acceleration (PGA) and the amplification may be visualized by the acceleration response spectra. In addition, the frequency content and the velocity of the ground motion are also important parameters that affect the dynamic behavior of structural systems. In particular, base-isolated buildings may be protected from ground motions including high frequencies and sharp accelerations effectively. On the contrary, when the base-isolated buildings are subjected to the near-fault ground motions, the isolation system may not be as effective and increases in the structural response parameters may be observed [4].

Long-period pulses with high peak ground velocities characterize the near-fault ground motions [5] and these pulses may have the potential for causing detrimental effects on flexible structures [6] such as base-isolated buildings. In case base-isolated buildings are located in near-fault regions where soil amplification may be observed, it may worsen the situation further.

In this study, we investigate the effect of soil amplification on the response of base-isolated buildings which are located in near-fault zones. To this aim, a synthetic pulse-like ground motion representing the near-fault earthquake 
records, which is assumed to be recorded at the bedrock level, is generated and a soil amplification analysis is conducted on this record for a representative benchmark soft soil to obtain the surface record. Then a benchmark base-isolated building is subjected to the original bedrock and the amplified surface records. Finally, the time history plots, the peak values, and the ratios of the peak values of several structural response parameters are compared.

\section{Base-Isolated Building}

\subsection{Superstructure}

In this study a five-story base isolated building obtained from Alhan et al. [7] which consists of moment resisting reinforced concrete frames is examined in order to investigate the effect of soil amplification on the response of base isolated buildings under near-fault earthquakes. Figure 1 shows a schematic three-dimensional view of the structural system. While the typical bay widths are $5.0 \mathrm{~m}$ both in $\mathrm{X}$ and $\mathrm{Y}$ directions, the story heights are $3.0 \mathrm{~m}$. The cross sectional dimensions of the beam and column members are $30 \mathrm{~cm} \times 50 \mathrm{~cm}$ and $45 \mathrm{~cm} \times 45 \mathrm{~cm}$, respectively. The concrete class of all structural members is C30 with a modulus of elasticity of $32000 \mathrm{MPa}$. Each of the five floors and the isolation floor are modeled as rigid-diaphragms with three degree of freedom per floor. Each floor including the base floor has $650 \mathrm{kNs} 2 / \mathrm{m}$ translational mass in both $\mathrm{X}$ and $\mathrm{Y}$ directions and $70416 \mathrm{kNs} 2 \mathrm{~m}$ rotational mass around $\mathrm{Z}$ axes, which are assumed to be lumped at the center of gravity. The fixed base period of the building in both of the translational directions is $0.65 \mathrm{~s}$.

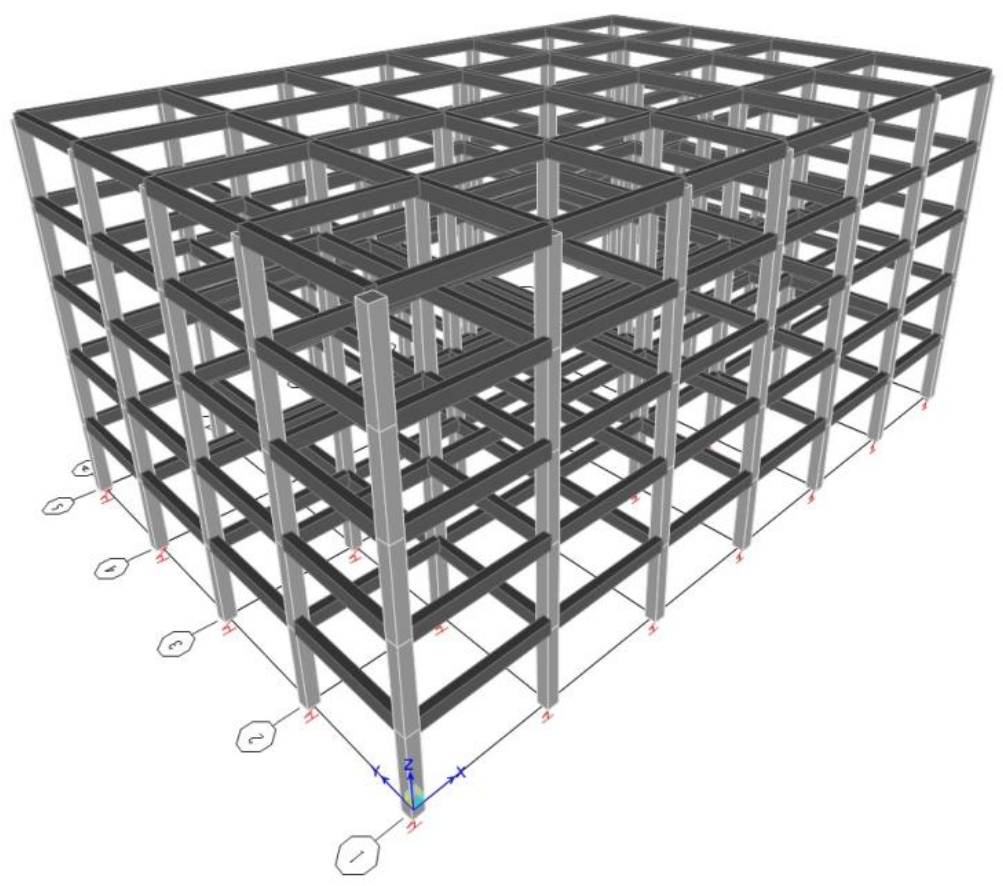

Fig. 1: Schematic three-dimensional view of the benchmark building.

\subsection{Base-Isolation System}

The base isolation system consists of identical nonlinear isolation bearings whose force-displacement behaviors are modeled as smooth bi-linear hysteretic which are located centrally underneath each column. The rigid-body mode period $\left(\mathrm{T}_{0}\right)$ of the base-isolated building, the characteristic strength ratio $(\mathrm{Q} / \mathrm{W})$ and the yield displacement $\left(\mathrm{D}_{\mathrm{y}}\right)$ of the isolation system are assumed to be $3.5 \mathrm{~s}, \% 10$ and $40 \mathrm{~mm}$, respectively. Therefore, post-yield to pre-yield stiffness ratio $(\alpha)$ and the yield strength $\left(\mathrm{F}_{\mathrm{y}}\right)$ are taken as 0.12 and $120.25 \mathrm{kN}$, respectively. The mathematical relations between the aforementioned characteristic parameters of an isolation system can be found elsewhere [8]. 


\section{Soil Profile}

The cross-sectional view and the characteristics of the soil profile, which is used in amplification analyses, are presented in Figure 2. This soil profile is obtained from a study by Özgirgin [9] and belongs to Mavişehir, İzmir which is located on the west side of Turkey. Mavişehir region of İzmir is a potential site to cause significant soil amplification. Furthermore, it is also a potential site for earthquake hazard which is classified in earthquake zone 1 with the design PGA of $0.40 \mathrm{~g}$ according to the current 2007 version of the Turkish Earthquake Code.

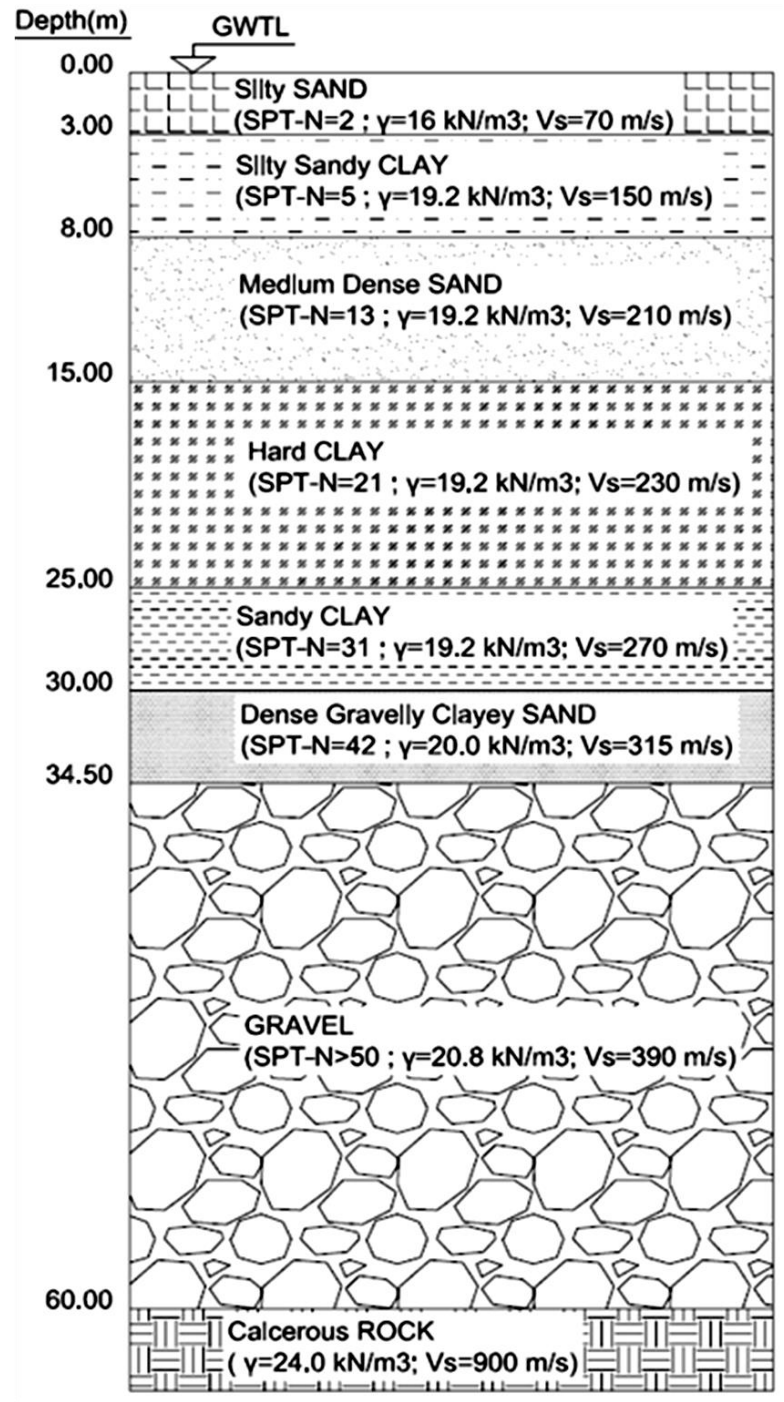

Fig. 2: Soil profile [9].

As seen in Figure 2, all layers in the stratum are under the groundwater table line. Moreover, blow numbers of the standard penetration test (SPT-N), which increases with depth, show that soil layers near the bedrock has greater stiffness than soil layers near the surface. Additionally, measured shear wave velocity [10] $\left(\mathrm{V}_{\mathrm{s}}\right)$ profile of the strata also has an increasing tendency with depth and supports the SPT-N values. The proposed soil dynamic behaviour models in literature presented in Table 1 are determined by evaluating both the SPT-N results and the depth of the soil layers; considering stress conditions and $\mathrm{V}_{\mathrm{s}}$ values. The thickness of the soil that is capable of amplifying bedrock earthquake record is approximately $60 \mathrm{~m}$. It includes both coarse and fine-grained, relatively weak layers. 
Table 1: Soils and implemented models.

\begin{tabular}{|c|c|c|}
\hline Material Name & $G / G_{\max }-\gamma_{s}(\%)$ Model & $D-\gamma_{s}(\%)$ Model \\
\hline Silty Sand & \multicolumn{2}{|c|}{$\mathrm{PI}=0 \%, \sigma_{\mathrm{c}}^{\prime}=0.25 \mathrm{~atm}[11]$} \\
\hline Silty Sandy Clay & $\begin{array}{c}\text { CLAY, PI }=10-20 \\
{[12]}\end{array}$ & $\begin{array}{c}\text { Soil with PI }=15, \text { OCR }=1-8 \\
{[13]}\end{array}$ \\
\hline Medium Dense Sand & \multicolumn{2}{|c|}{ SAND, Average [14] } \\
\hline Medium Clay & \multicolumn{2}{|c|}{$\mathrm{PI}=50 \%$ - Effective Confining Pressure $=16.0$ atm [11] } \\
\hline Sandy Clay & $\begin{array}{c}\text { CLAY, PI }=10-20 \\
{[12]}\end{array}$ & $\begin{array}{c}\text { Soil with PI }=15, \text { OCR }=1-8 \\
{[13]}\end{array}$ \\
\hline Dense Gravelly Clayey Sand & \multicolumn{2}{|c|}{ SAND, Lower Bound [14] } \\
\hline Gravel & \multicolumn{2}{|c|}{ GRAVEL, Average [15] } \\
\hline Calcerous Rock & \multicolumn{2}{|c|}{ ROCK [16] } \\
\hline
\end{tabular}

\section{Earthquake Data}

\subsection{Bedrock Motion}

In this study, the bedrock motion is considered as a pulse-like near-fault ground motion. Since this kind of ground motions can be modeled with pulse models, a pulse model is used to generate the synthetic bedrock motion record representing near-fault ground motion characteristics. In order to simulate the pulse-like ground motions, there are several analytical pulse models proposed by various researchers $[6 ; 4 ; 5 ; 17]$. Since Agrawal and He [5] pulse model has significant advantages arising from its simpler time domain expression, we made use of Agrawal and He [5] pulse model to generate the synthetic bedrock motion record.

The closed-form approximation proposed for the velocity time history $(\mathrm{v}(\mathrm{t}))$ of pulse-like near-fault ground motios by Agrawal and He [5] is given Equation 1. In this equation, $\zeta \mathrm{p}$ is the damping factor for the decaying sinusoid, while $\omega \mathrm{p}$ is the circular frequency and $\mathrm{s}$ is the initial amplitude of the velocity pulse.

$$
\mathrm{v}(\mathrm{t})=\mathrm{s} e^{-\zeta_{p} \omega_{p} t} \sin \left(\omega_{p} t \sqrt{1-\zeta_{p}^{2}}\right)
$$

The velocity time-history of the bedrock motion, generated using Equation 1 and assuming the earthquake moment magnitude as $\mathrm{Mw}=6.5$ and the closest distance to the fault as $\mathrm{r}=3 \mathrm{~km}$ with $\omega \mathrm{p}=3.50 \mathrm{rad} / \mathrm{s}$ and s$=136.40 \mathrm{~cm} / \mathrm{s}$, is plotted in Figure 3 with the dashed line. 10\% damped displacement spectrum of this record is also given in Figure 4 with the dashed line. Pulse period is dependent on earthquake moment magnitude while pulse amplitude is dependent on both moment magnitude and fault distance through the relations set forth by Somerville [18] for real earthquakes, recorded.

\subsection{Surface Ground Motion}

In scope of this study, the soil amplification analysis is carried out using software EERA [19]. First of all, the soil profile given in Figure 2 is defined in EERA and then the dynamic response and the behavior of soil layers are described in terms of G/Gmax- $\gamma$ s (\%) and D- $\gamma$ s (\%) by implementing the models given in Table 1. Initial estimated damping (Di) is assigned as $5 \%$ for all layers, except for bedrock $(\mathrm{Di}=0)$. Initial shear moduli (Gmax) of the layers are calculated by Equation 2, where $\rho$ is the unit mass of the soil, embedded in EERA. Finally, input ground motion, which is produced artificially, is assigned to calcerous rock layer and eventually soil response analyses are processed (see Figures $3 \mathrm{a}$ and $3 \mathrm{~b}$ ).

$$
G_{\max }=\rho V_{s}^{2}
$$




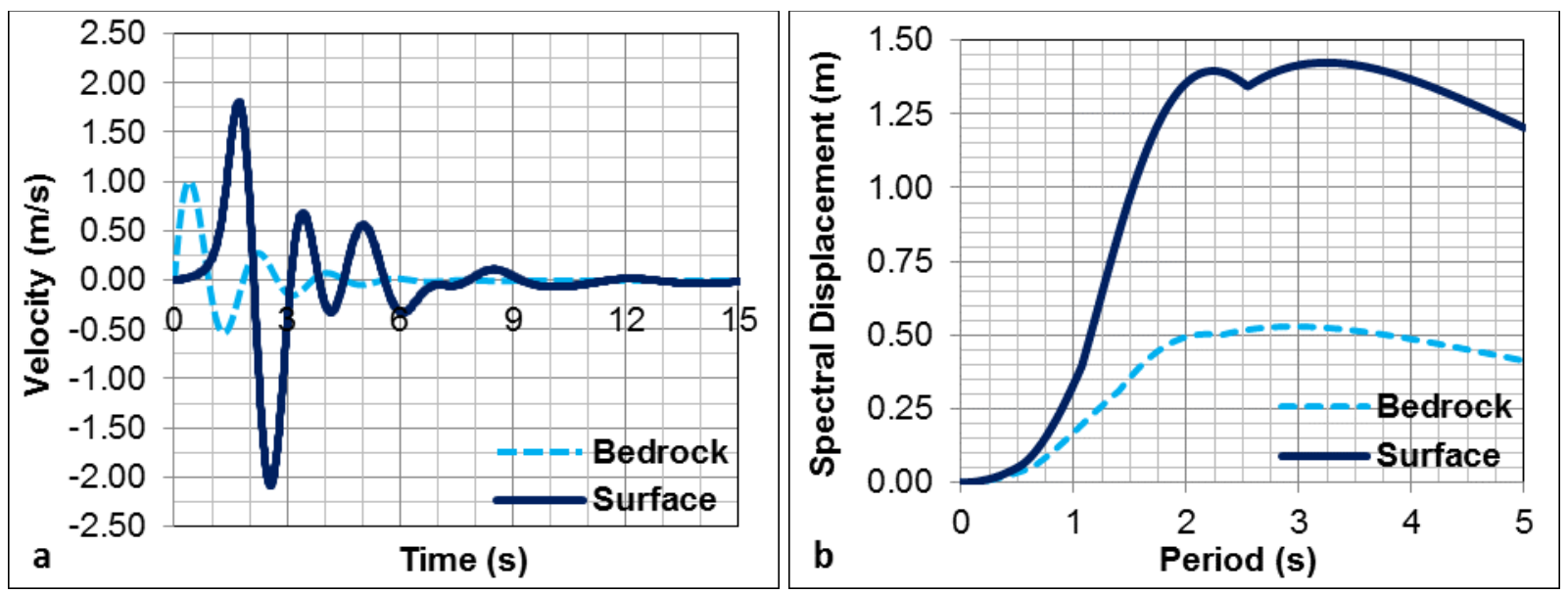

Fig. 3: (a) Velocity time histories and (b) Displacement spectra (10\% damped) of the records.

\section{Time History Analyses and Results}

In order to investigate the effects of soil amplification on the dynamic response of base-isolated buildings under nearfault earthquakes, the structural model described in Section 2 is subjected to both of the bedrock and surface ground motions described in Section 4. Then, nonlinear dynamic analyses are conducted in 3D-BASIS [20], which is an academic software developed for nonlinear dynamic analysis of three dimensional base-isolated structures. In this section, the results of these analyses are presented. The floor accelerations, story shear forces, relative displacements of each floor with respect to the base floor, inter-story drift ratios obtained at the center of mass of floors, base displacement, structural shear force, and base shear force are considered as the structural response parameters. The time history plots of the base displacement at the center of mass of base, the top floor acceleration at the center of mass of the top floor, the structural shear force, and the relative displacement of the top floor with respect to base, which are obtained under both the bedrock and the amplified surface ground motions, are given in Figures $4 \mathrm{a}, 4 \mathrm{~b}, 4 \mathrm{c}$, and $4 \mathrm{~d}$, respectively. It is seen from all these plots that there is a significant difference between the time histories of the subject structural response parameters, in particular during the main-shock time bracket.

As for the peak base displacement, the peak floor accelerations, the peak story shear forces, the peak base shear force, the peak relative displacements of the floors with respect to the base floor, and the peak inter-story drift ratios obtained under the bedrock and surface ground motions, they are presented in Figures 5a, 5b, 5c, 5d, 5e, and 5f, respectively. As seen in Figure 5a, the peak base displacements obtained under the bedrock and the surface ground motions are $0.469 \mathrm{~m}$ and $1.474 \mathrm{~m}$, respectively. The peak floor accelerations obtained under the bedrock ground motion vary between $2.51 \mathrm{~m} / \mathrm{s}^{2} \sim$ $3.08 \mathrm{~m} / \mathrm{s}^{2}$, whereas the peak floor accelerations obtained under the surface ground motion vary between $5.62 \mathrm{~m} / \mathrm{s}^{2} \sim 6.71$ $\mathrm{m} / \mathrm{s}^{2}$, as seen in Figure 5b. The peak story shear forces obtained under the bedrock and the surface ground motions vary between $1973 \mathrm{kN} \sim 8320 \mathrm{kN}$ and $4300 \mathrm{kN} \sim 18944 \mathrm{kN}$, respectively (Figure 5c). As seen in Figure 5d, the peak base shear forces obtained under the bedrock and the surface ground motions are $9456 \mathrm{kN}$ and $21740 \mathrm{kN}$, respectively. The peak floor relative displacements (w.r.t base) under the bedrock ground motion vary between $0.8 \mathrm{~cm} \sim 3.5 \mathrm{~cm}$, whereas the peak floor relative displacements (w.r.t base) under the surface ground motion vary between $1.8 \mathrm{~cm} \sim 7.9 \mathrm{~cm}$ (Figure 5e). While the peak inter-story drift ratios obtained under the bedrock ground motion vary between $1.1 \times 10^{-3} \sim 3.4 \times 10^{-3}$, under surface ground motion they vary between $2.3 \times 10^{-3} \sim 7.6 \times 10^{-3}$ (Figure $5 \mathrm{f}$ ).

In order to reveal the significance of the effect of the soil amplification on the response of base-isolated buildings, the ratios of the peak values of the structural response parameters (response to surface / response to bedrock) given in Figure 5 are represented in Figure 6. It is seen from Figure 6a that, the ratio between the peak base displacements obtained under the surface and bedrock motions is equal to 3.14. Likewise, the ratio between the peak base shear forces under the same ground motions is high and equal to 2.30. The ratios of the peak story shear forces, the peak relative displacements with respect to base, and the peak inter-story drift ratios also show a similar trend and the values vary in a range of 2.15 to 2.30 , while the peak floor acceleration ratios vary in a relatively wider range of 2.05 to 2.30 . 

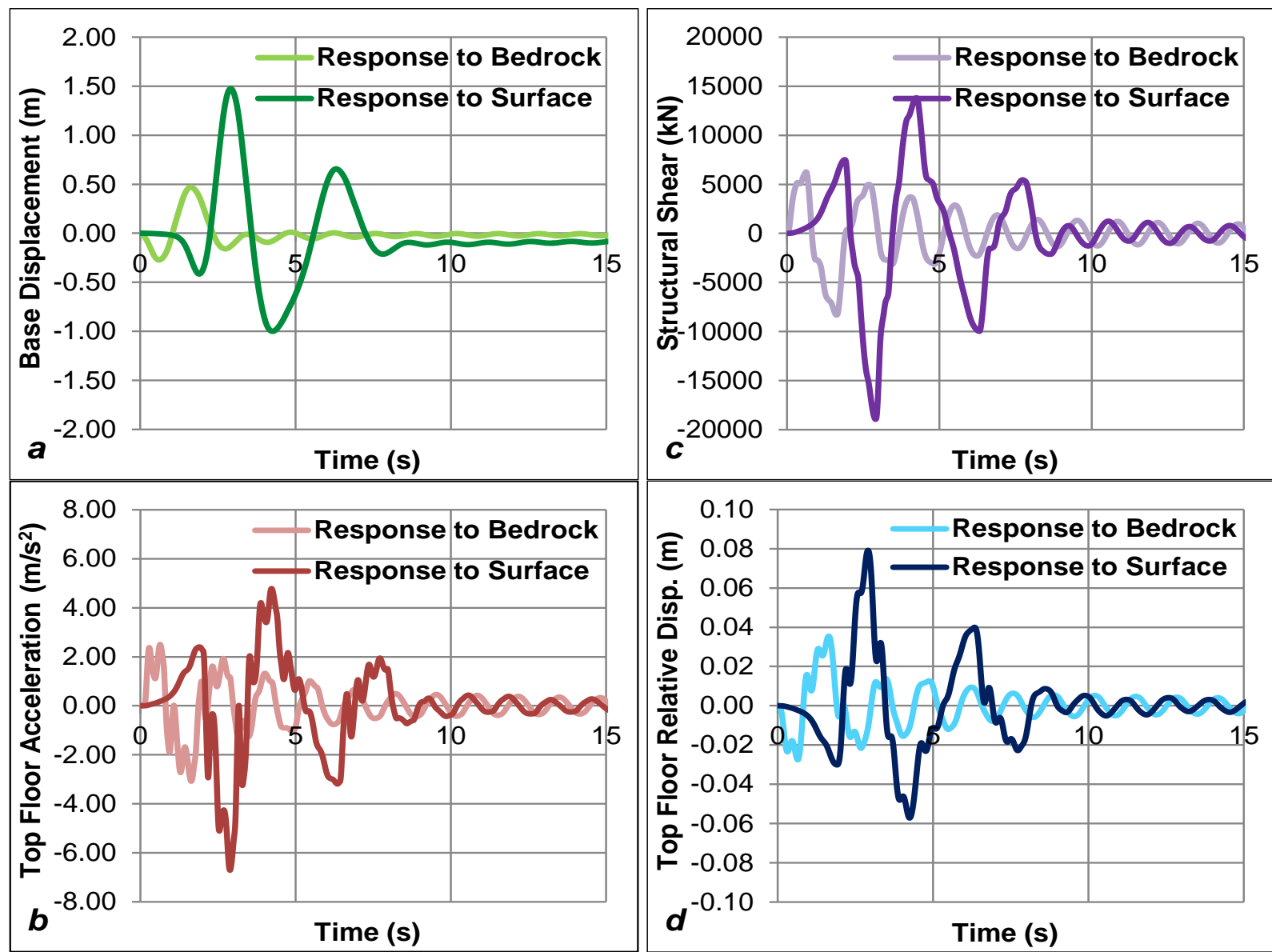

Fig. 4: Time history plots of the structural response parameters obtained under bedrock and surface ground motions.

\section{Conclusions}

By making use of the seismic response analyses of a benchmark base-isolated building under (i) a synthetic pulse-like ground motion assumed to be recorded at bedrock and (ii) the corresponding surface record obtained via a soil amplification analysis for a representative benchmark soft soil, the effect of soil amplification on the response of baseisolated buildings that are located in near-fault zones is investigated in this study. Based on the limited parametric analyses conducted here, it is concluded that base displacement, base shear, and the superstructure response parameters including floor accelerations, story shears, floor displacements with respect to base, and drift ratios may be significantly amplified (more than two folds) due to the effect of soil amplification in near-fault zones.

Ongoing research considers a wider range of parameters including the isolation system period, isolation system characteristic strength, and pulse periods. 


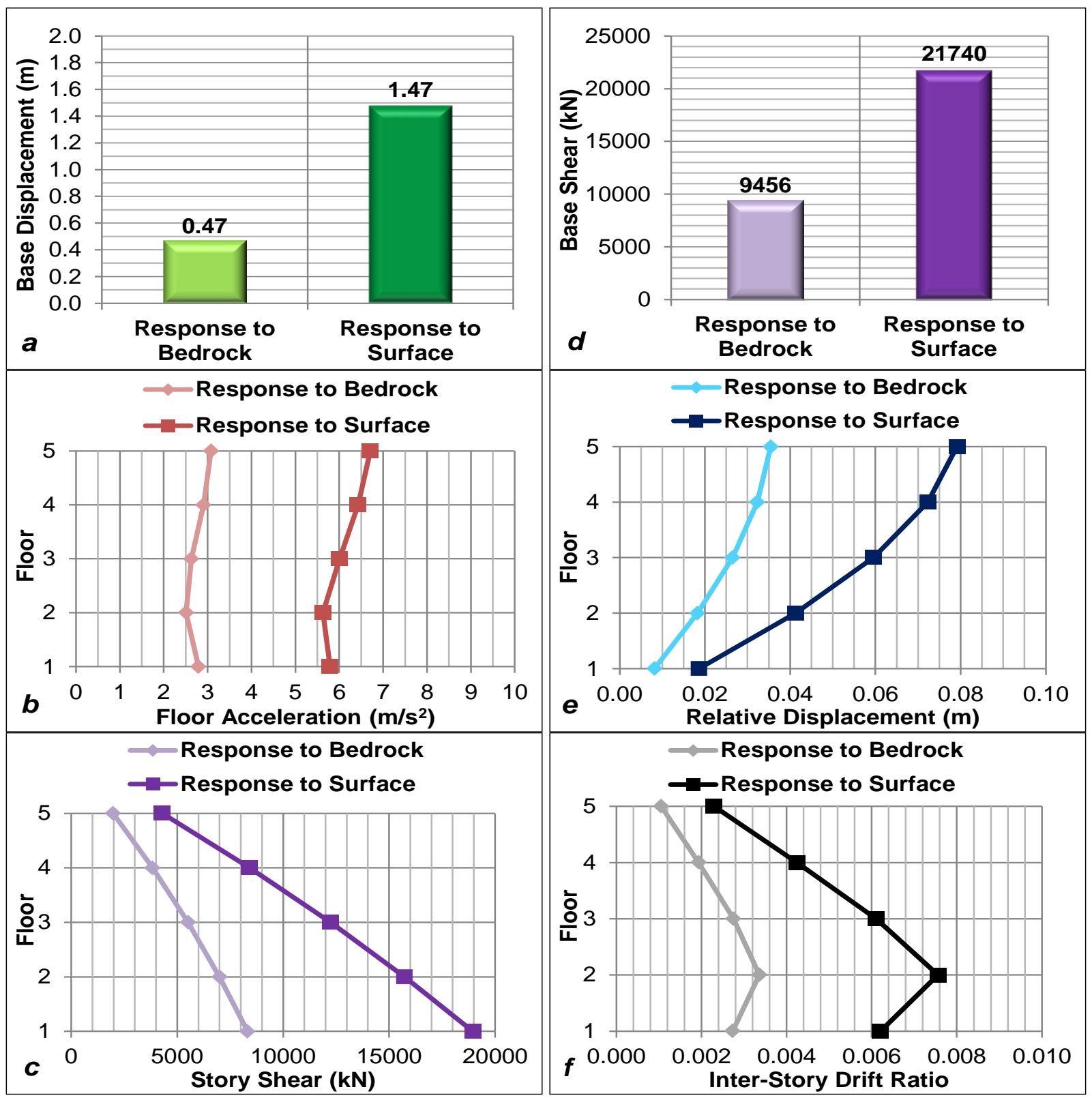

Fig. 5: Peak values of the structural response parameters obtained under bedrock and surface ground motions.
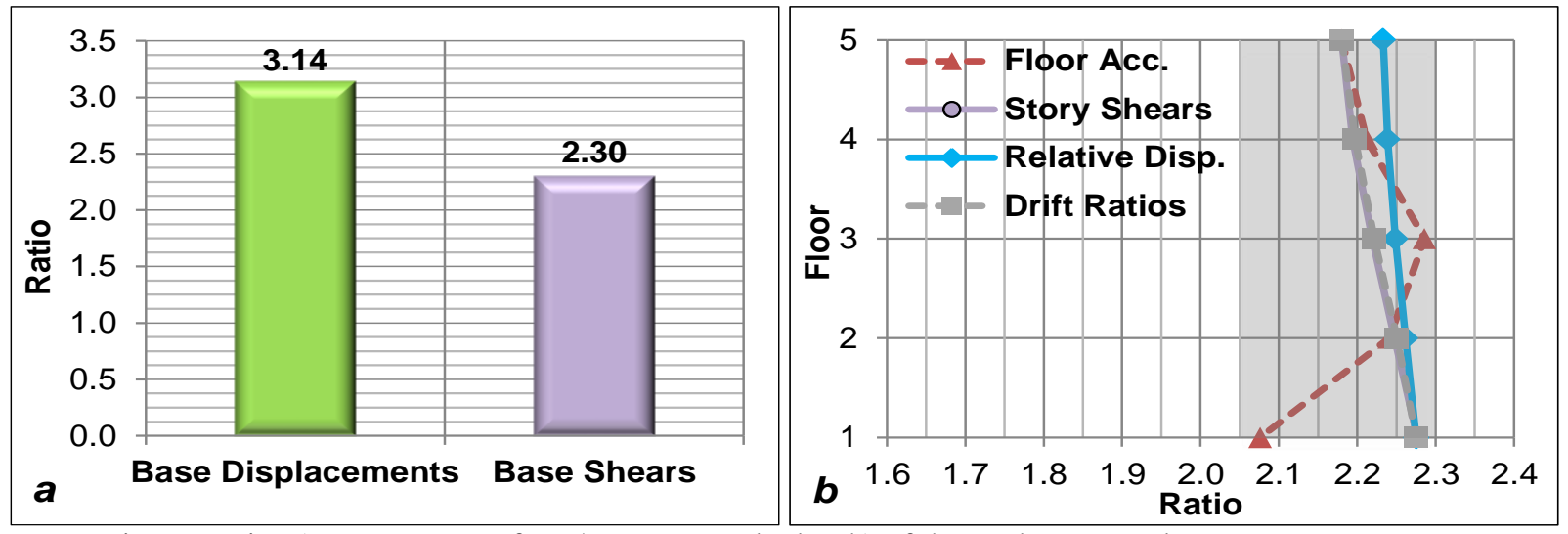

Fig. 6: Ratios (response to surface / response to bedrock) of the peak structural response parameters. 


\section{Acknowledgements}

We would like to acknowledge The Scientific Research Projects Coordination Unit of Istanbul University (IU BAP) for providing financial support under Project No: BEK-23445.

\section{References}

[1] H. B. Seed, M. P. Romo, J. I. Sun, A. Jaime and J. Lysmer, "Relationships between soil conditions and earthquake ground motions in Mexico City in the earthquake of Sept. 19, 1985," Report No: UCB/EERC-87/15, University of California, Berkeley, 1987.

[2] A. Rodriguez-Marek, J. D. Bray and N. Abrahamson, "Task 3: Characterization of site response general site categories," Report No: PEER 1999/03, University of California, Berkeley, 1999.

[3] R. Borcherdt, G. Glassmoyer, M. Andrews and E. Cranswick, "Effect of site conditions on ground motion and damage," Armenia Earthquake Reconnaissance Report, Earthquake Spectra Special Supplement, 1989.

[4] N. Makris, "Rigidity, plasticity, viscosity: can electrorheological dampers protect base isolated structures from near source ground motions?," Earthquake Engineering and Structural Dynamics, vol. 26, no. 5, pp. 571- 591, 1997.

[5] A. K. Agrawal and W. L. He, "A closed form approximation of near fault ground motion pulses for flexible structures," in Proc. of the 15th ASCE Engineering Mechanics Conference, New York, 2002.

[6] J. F. Hall, T. H. Heaton, M. W. Halling and D. J. Wald, "Near-source ground motion and its effects on flexible buildings," Earthquake Spectra, vol. 11, no. 4, pp. 569-605, 1995.

[7] C. Alhan, S. Öncü-Davas and H. Gazi, "Evaluation of content damage ratios of seismically isolated buildings under earthquake loading," in Proceedings of Vienna Congress on Recent Advances in Earthquake Engineering and Structural Dynamics 2013 (VEESD 2013), Austria, 2013.

[8] F. Naeim and J. M. Kelly, Design of seismic isolated structures: from theory to practice. John Wiley \& Sons Inc., New York, 1999.

[9] F. Özgirgin, "Case studies on soil amplification,” M.S. thesis, Boğaziçi University, Turkey, 1997.

[10] ZETAS, "Zemin Teknolojisi A.S.,T. Emlak Bankası İzmir Mavişehir Konutları Site Investigation Report,” 1994.

[11] M. B. Darendeli, "Development of a new family of normalized modulus reduction and material damping curves," Ph.D. dissertation, The University of Texas Austin, Texas, USA, 2001.

[12] J. I. Sun, R. Golesorkhi and H. B. Seed, "Dynamic moduli and damping ratios for cohesive soils," Report No: EERC 88-15, University of California, Berkeley, 1988.

[13] M. Vucetic and R. Dobry, "Effect of soil plasticity on cyclic response," Journal of Geotechnical Engineering (ASCE), vol. 117, no. 1, pp. 89-107, 1991.

[14] H. B. Seed and I. M. Idriss, "Soil moduli and damping factors for dynamic response analyses," Report No: EERC 70-10, University of California, Berkeley, 1970.

[15] H. B. Seed, R. T. Wong, I. M. Idriss and K. Tokimatsu, "Moduli and damping factors for dynamic response analyses of cohesionless soils," ASCE Journal of Geotechnical Engineering, vol. 112, no. 11, pp. 1016-1032, 1986.

[16] P. B. Schnabel, "Effects of local geology and distance from source on earthquake ground motions," Ph.D. dissertation, University of California, Berkeley, 1973.

[17] W. L. He and A. K. Agrawal, "An analytical model of ground motion pulses for the design and assessment of smart protective systems," ASCE Journal of Structural Engineering, vol. 134, no. 7, pp. 1177-1188, 2008.

[18] P. G. Somerville, "Development of an improved representation of near-fault ground motions," in Proceedings of SMIP98: Seminar on utilization of strong-motion data, Oakland, CA, 1998.

[19] J. P. Bardet, K. Ichii and C. H. Lin, "EERA: A computer program for equivalent-linear earthquake site response analyses of layered soil deposits," University of Southern California, 2000.

[20] S. Nagarajaiah, A. M. Reinhorn and M. C. Contantinou, "3D-Basis: A general program for the nonlinear dynamic analysis of three dimensional base isolated buildings," Department of Civil Engineering State University, Buffalo, 1990. 